\title{
Video-assisted thoracoscopic surgery (VATS) right upper lobectomy for non-small-cell lung cancer with an azygos lobe
}

\author{
Ozgur Samancilar, Tevfik Ilker Akcam, Seyda Ors Kaya, Serpil Sevinc, Onur Akcay, Kenan Can Ceylan \\ Department of Thoracic Surgery, Dr. Suat Seren Chest Diseases and Thoracic Surgery Training and Research Hospital, Izmir, Turkey
}

Kardiochirurgia i Torakochirurgia Polska 2016; 13 (4): 373-374

\begin{abstract}
Although it is not a pathologically significant entity, cases of azygos lobe $(\mathrm{AL})$ are interesting due to the difficulty of performing video-assisted thoracoscopic surgery (VATS) procedures in the affected patients and the presence of a congenital malformation. Currently, videothoracoscopic surgery has advanced to such a level that most thoracic procedures can be performed with video assistance. However, some technical difficulties may arise in cases with anatomical anomalies such as AL. This report presents the case of a patient with an azygos lobe who underwent videothoracoscopic lung resection due to the presence of non-small-cell lung carcinoma in the upper lobe of the right lung.
\end{abstract}

Key words: azygos lobe, lung cancer, videothoracoscopic resection.

\section{Introduction}

An azygos lobe $(\mathrm{AL})$ is the best known and most common malformation of the lungs [1]. It is a defect which develops during the migration of the azygos vein in the embryonic period. It is possible to find reports of procedures performed in patients with an azygos lobe in the literature $[1,2]$. However, the presence of the azygos vein complicates procedures performed in the upper area of the right hemithorax, especially if the planned procedure is to employ videothoracoscopy [2]. The present study examines the case of a patient with an azygos lobe, who underwent videothoracoscopic lung resection due to the presence of non-smallcell lung carcinoma in the upper lobe of the right lung.

\section{Case report}

A homogeneous increase in density with a diameter of approximately $2 \mathrm{~cm}$ at the upper zone of the right hemithorax was observed on a chest X-ray obtained for screening purposes in the case of a 55-year-old male patient with no comorbidities. On the right side, the image suggested the

\section{Streszczenie}

Choć opisywana jednostka nie jest patologicznie istotna, przypadki z płatem żyły nieparzystej są interesujące ze względu na trudność przeprowadzenia zabiegu wideotorakoskopowego (VATS) u takich pacjentów oraz obecność wrodzonej malformacji. Chirurgia wideotorakoskopowa rozwinęta się do tego stopnia, że większość zabiegów w obrębie klatki piersiowej można wykonywać z wykorzystaniem obrazu wideo. Operowanie pacjentów z wariantami anatomicznymi, takimi jak płat żyły nieparzystej, może się jednak wiązać z pewnymi technicznymi trudnościami. W niniejszej pracy przedstawiono przypadek pacjenta z płatem żyły nieparzystej, który został poddany wideotorakoskopowej resekcji płuca z powodu obecności niedrobnokomórkowego raka płuca w górnym płacie prawego płuca.

Słowa kluczowe: płat żyły nieparzystej, rak płuca, resekcja wideotorakoskopowa.

presence of an azygos vein. The advanced tests that were ordered included thoracic computed tomography (CT), which revealed a lesion measuring $2.1 \times 2 \mathrm{~cm}$ in the anterior part of the right lung's upper lobe (Fig. 1). Transthoracic fine needle aspiration biopsy revealed non-small-cell lung cancer with cytomorphological findings compatible with adenocarcinoma. No other metastatic foci were found in the systemic screening tests. Since the patient's forced expiratory volume in $1 \mathrm{~s}\left(\mathrm{FEV}_{1}\right)$ was $2630 \mathrm{ml}$ and $89 \%$, and since no abnormality was present in the laboratory tests, a decision was made to perform surgery. Right upper lobectomy with mediastinal lymph node dissection was performed by VATS. The azygos lobe was exposed during the operation (Fig. 2). The membrane on the azygos lobe was resected, and the lobe was freed by being pulled below the azygos vein. Subsequently, a right upper lobectomy was performed using an anterior hilar approach through three $1 \mathrm{~cm}$ thoracoports and a $4 \mathrm{~cm}$ utility incision.

A wide area was created under the azygos vein, which facilitated the dissection of the right upper and lower paratracheal ( $2 R$ and $4 R$ ) lymph nodes. The thoracic drain was

Address for correspondence: Tevfik Illker Akçam MD, 6754/3 st. N: 3/G Yuksek Vadi House, Karsıyaka, 35510 Izmir, Turkey, phone: +90 5386062581, e-mail: tevfikilkerakcam@hotmail.com

Received: 20.10.2015, accepted: 17.11.2016. 


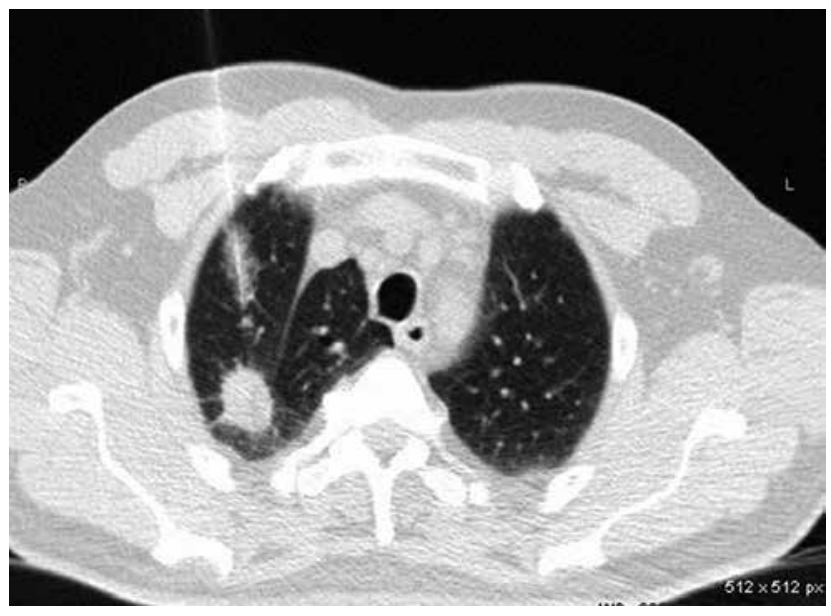

Fig. 1. Thoracic computed tomography (CT): a $2.1 \times 2 \mathrm{~cm}$ lesion in the anterior part of the right lung's upper lobe (an azygos lobe)

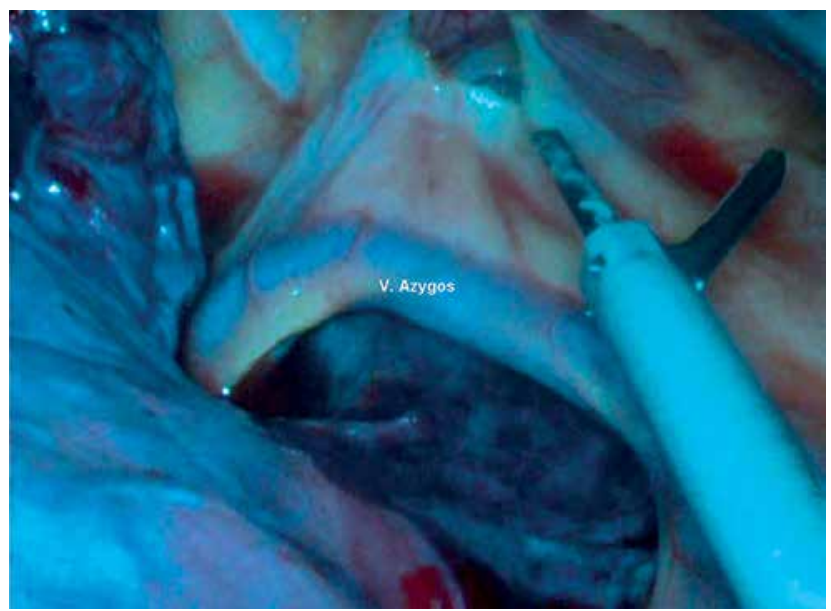

Fig. 2. Intraoperative image of the azygos lobe

removed on the fourth day after the operation as no complications developed postoperatively.

\section{Discussion}

An azygos lobe, located in the superior part of the right hemothorax, is one of the congenital abnormalities of the lung. The mechanism of its development is that the azygos vein passes anteriorly to the lung; as a result, some segments of the right upper lobe remain in this structure $[1,3,4]$. It is a congenital variation seen in $0.11-1.06 \%$ of the population [3]. It has no serious consequences by itself, and there is no need for special treatment; however, accompanying conditions may warrant attention. Bronchial carcinoma, pneumothorax, bullous changes, and vascular abnormalities have been reported to accompany AL [1, 5-7]. Various approaches have been successfully employed for those pathological conditions. The first report of a right upper lobectomy by VATS in a patient with an AL was published by Arai et al. [1]. Although the diagnosis of an AL is generally made on the basis of a chest X-ray, computed tomography might be required in some cases to provide more accurate results [4]. Some other cardiopulmonary pathologies might be present in patients with AL; it is important to keep this in mind when examining such patients. In the case reported herein, the results of echocardiographic examination were normal, and no other congenital abnormality was encountered.

In addition to right upper lobe tumors developing next to the azygos lobe, some tumors may originate directly from the azygos lobe. The number of studies on the subject is limited; however, it is worth noting the report by Fukuhara et al. [5], in which a patient with non-small-cell lung cancer originating from the azygos lobe was operated on using a robot-assisted technique.

The presence of an AL is considered a complicating factor, especially in cases in which videothoracoscopic sympathectomy is planned. Some studies were performed on this subject [2], in which the presence of an azygos lobe was considered to complicate the procedure of sympathectomy; however, the authors suggested that the procedure may be completed with videothoracoscopy without any complications provided that certain appropriate steps are followed.

\section{Conclusions}

Currently, videothoracoscopic surgery has advanced to such a level that most thoracic procedures can be performed using video assistance. However, some technical difficulties may arise in cases with anatomical variations such as AL. Videothoracoscopic procedures can be successfully performed in spite of these difficulties. Moreover, with the growing number of performed procedures and shared experiences, these difficulties will be overcome more easily. We believe that this report can contribute to the literature as only a limited number of studies have been published on the subject.

\section{Disclosure}

Authors report no conflict of interest.

\section{References}

1. Arai H, Inui K, Kano K, Nishii T, Kaneko T, Mano H, Sasaki T, Masuda M. Lung cancer associated with an azygos lobe successfully treated with video-assisted thoracoscopic surgery. Asian J Endosc Surg 2012; 5: 96-99.

2. Kauffman P, Wolosker N, de Campos JR, Yazbek G, Jatene FB. Azygos lobe: a difficulty in video-assisted thoracic sympathectomy. Ann Thorac Surg 2010; 89: 57-59.

3. Rauf A, Rauf WU, Navsa N, Ashraf KT. Azygos lobe in a South African cadaveric population. Clin Anat 2012; 25: 386-390.

4. Aziz A, Ashizawa K, Nagaoki K, Hayashi K. High resolution CT anatomy of the pulmonary fissures. J Thorac Imaging 2004; 19: 186-191.

5. Fukuhara S, Montgomery M, Reyes A. Robot-assisted azygos lobectomy for adenocarcinoma arising in an azygos lobe. Interact Cardiovasc Thorac Surg 2013; 16: 715-717.

6. Gürkök S, Gözübüyük A, Yücel O, Çaylak H, Dakak M. A case of bullous azygos lobe. Turk J Thorac Cardiovasc Surg 2007; 15: 168-169.

7. Monaco M, Barone M, Barresi P, Carditello A, Pavia R, Mondello B. Azygos lobe and spontaneous pneumothorax. G Chir 2000; 21: 457-458. 